
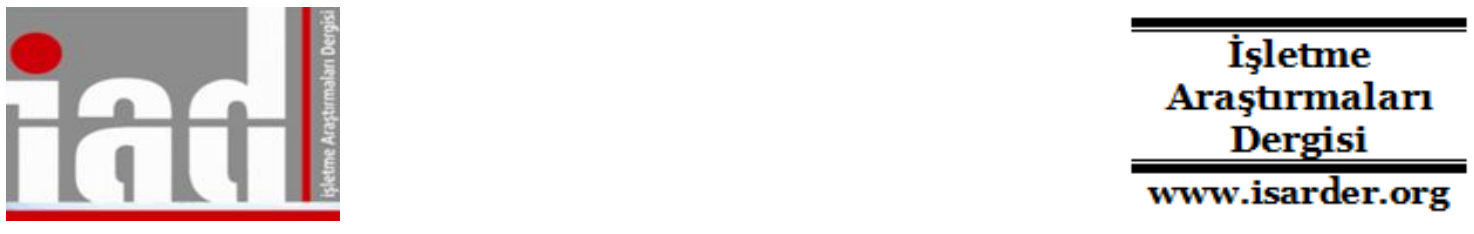

\title{
A Focus on Far Eastern Tourists - Tour Operator Selection Criteria
}

\author{
Ayşe Çelik \\ Muğla Sitkı Koçman University \\ Fethiye Faculty of Business, \\ Department of Tourism Administration, \\ Muğla, Turkey \\ aysecelik@mu.edu.tr
}

\begin{abstract}
Tour operators are becoming more important in the long haul destination market. Identifying tour operator selection criteria is crucial to orientate marketing strategies. The aim of the study was to determine the tour operation selection criteria of a package holiday maker visiting Turkey from the Far East according to the nationality. Data was drawn up and analyzed from tourists who came from three of these countries namely: Japan, South Korea, and China between February and April 2013 in Cappadocia. Quantitative methodology employing One-way ANOVA analysis was used. Deduction was made by analysing the tour operator selection criteria data that nationality was not a meaningful differentiation for a tourist in their assessment of the "Service Quality" and "Opportunity to interact with other people" items referred to in the survey questionnaire. Other items from the resulting data gave meaningful differences in crosscultural behaviour. Results from the study provide important cues for tour operator managers to consider developing different promotional strategy initiatives to engage and attract more Japanese, South Korean, and Chinese tourists to Turkey.
\end{abstract}

Keywords: Tour Operator Selection Criteria, Cross-Cultural Tourist Behaviour, Far Eastern Tourism Market.

\section{Introduction}

Tour operators supply international tourist flow to many destinations all over the World i.e. they play a significant part in the movement as well as the volume of global tourism) (Cavlek, 2002). Tour operators operate as intermediaries in the tourism distribution system connecting producers and consumers (Gartner and Bachri, 1994). According to The World Tourism Organization's estimates, tour operators nowadays have a share of about $25 \%$ of the total international tourism market (Cavlek, 2002). Kotler, Bowen and Makens (1996: 483) outlined the meaning of the distribution channel concept as: "A set of interdependent organizations involved in the process of making a product or service available for use or consumption by the consumer or business user". Within the stages of this distribution process, tour operators can be defined as the wholesalers of the travel industry i.e. purchasing their package holidays from its principals and reselling them through its retailers (Yale, 1995). 


\section{A. Çelik 6/1 (2014) 32-41}

For many years, tour operators have traditionally produced what we now commonly refer to as package holidays. In other words they have arranged vacations that include transport, accommodation, ground arrangements and the services of a tour operator's representative for an all-in-price holiday deal (Horner, 1996: 174). A tourist's motivation for participating on any given package tour are numerous but they commonly include a desire for: a change of scenery, adventure, escapism, an educational experience, a pleasant climate, a chance to meet new people, visiting friends and relatives, shopping and cultural experiences (Reilly,1982:3).

This research is aimed at statistically analysing the way that Japanese, South Korean and Chinese cultural package holiday makers select tour operators and the research also reveals the relationship between tour operator selection criteria and tourist satisfaction. Convenience sampling, which is a non-probability sampling method was used with qualitative methodology. Zhang's (2008) questions relating to hotel selection criteria were adapted for testing the tour operator industry and they were sent in the form of a questionnaire to 10 tour operator managers in Cappadocia for their professional comment. A pilot test was made with a 150 far eastern tourists from Japan, South Korea and China who used tour operators for their package holiday. Cronbach's Alpha was assessed at a figure of 0.865 within the main survey which was completed by 707 of the Far Eastern tourists.

\section{Cultural Behaviour of the Far East Tourist Market - Literature Review}

Cross-cultural consumer behavioural studies have become an important subject in recent years. Halls (1969) separated the cultures into high and low contextual, cultural traits. Trompenaars (1994) researched culture by making various comparatives such as: Universalist versus particularistic cultures, individualist versus collectivist cultures, neutralist versus effective cultures, specificity versus diffusive cultures, achievementoriented versus ascription-oriented cultures, sequential versus synchronic cultures, and internal control versus cultural classification external control. Hofstede (1991) provided a noteworthy cultural classification database. He categorized cultural behaviour into five dimensions: a power distance dimension, individualism versus collectivism dimension, a masculinity versus feminity dimension, an uncertainty avoidance dimension and a long-term orientation dimension.

There have only been a few published research articles in tourism literature on cross-cultural behaviour. Woodside and Lawrence's (1985) study deduced that Canadians, Americans and Japanese had different perceptions of the benefits they experienced from their tours. Sheldon and Fox (1988) showed that in contrast with American and Canadian tourists, food services were one of the more significant features that effected the Japanese tourist's choice of destination. Pizam and Sussman's (1995) examination of British tour guides opinions on Japanese, French, Italian and American tourists, discovered that Japanese tourists were seen as being the most distinctive in their choice of 20 behavioural characteristics. Moreover in reviewing cross- cultural behaviour, Pizam and Jeong (1996) deduced that American tourists were the most distinctive nationality in comparison with Japanese, and Korean tourists according to the Korean tour guides.

Japan, China and South Korea tourists are the three most important far eastern countries buying into the Turkish tourism market (Ministry of Culture and Tourism, 2012).The Japanese market is growing at the fastest and it has important potential for the global tourism market (Surman, 2009: 193; Ahmed \& Krohn, 1992: 73). The 


\section{A. Çelik 6/1 (2014) 32-41}

Japanese market is made up of a collectivist and homogeneous cultural community structure. As a whole the Japanese have familiar tastes and life styles (Mak, 2004: 39 cited Varley, 2000) and the general touristic behaviour of the Japanese is that they: give high importance to the quality of a touristic product, generally have limited time periods for their vacations, have a foreign language handicap and low levels of trust.

Chinese now make up one quarter of the global tourism market and have huge purchasing power (Mok \& DeFranco, 1999: 99). A conceptual framework of the dominant Chinese cultural values are that they are: respectful of authority, interdependent, group orientated, harmonious. All-inclusive package holidays are mostly chosen by Hong Kong tourists (Luk, 1993; Mok \& Armstrong, 1995). For Hong Kong tourists' the most important criterion in their selection of a package holiday is the level of safety of the tour. Other prominent criteria include: the accuracy of departure dates and the service quality of travel agencies in general (Wong \& Kwong, 2004).

Korean tourists have both orientalist and western community cultural traits. However, according to Pizam \& Jeong, (1996: 278) Koreans can also be described as being at variance with western cultural travel. They have a tendency to have an unwavering loyalty to their socio-cultural identity and are unwilling to accept anything that is alien to the Korean life style. They insist on going to Korean restaurants while abroad, are fond of travelling to Asian countries that are based on Confucian Philosophy like in Korea and they prefer to travel in groups rather than individually. They usually feel comfortable with cash in hand and tend to show off their cash and spend freely.

\section{Methodology}

The aim of this study was to determine the Far Eastern Tourism Market Selection Criteria of Tour Operator and to show the differentiation of the same by nationality and cultural traits. Further the study reveals the relationship between tour operator selection criteria and tour satisfaction.

To do this a measurement of the aesthetic value of tour operators' touristic products was essentially required. The Aesthetic Value Scale was used to measure: a souvenir shop, museum, hotel, restaurant and the transportation used within the tour operators' package tour. This was performed as a one day evaluation.

Table 1: Tourist arrivals to Turkey Between 2003-2012 from Japan, South Korea and China

\begin{tabular}{|llll|}
\hline Years & Japan & South Korea & China \\
2003 & 67874 & 46405 & 27557 \\
2004 & 64318 & 56926 & 35339 \\
2005 & 116969 & 91597 & 44077 \\
2006 & 125755 & 108140 & 56323 \\
2007 & 168852 & 135124 & 68252 \\
2008 & 149731 & 119500 & 61882 \\
2009 & 147641 & 89148 & 69336 \\
2010 & 195404 & 123315 & 77142 \\
2011 & 188312 & 149943 & 96701 \\
2012 & 203592 & 159084 & 114582 \\
\hline
\end{tabular}

Ministry of Culture and Tourism, 2013. 


\section{A. Çelik 6/1 (2014) 32-41}

The universe of the study was a group of Far East tourists who visited Turkey. In 2012 the Ministry of Culture and Tourism reported that Japan, South Korea, China, Indonesia, India, Singapore, Malaysia, Thailand, Bangladesh, and Pakistan were the most prominent Far Eastern countries that visited Turkey. The chosen sample of the study was limited to Japanese, South Korean and Chinese tourists as these countries were recorded as being the ones that visited the Cappadocia Region the most between February and April 2013. The aim of selecting the Far Eastern Tourist was to measure their aesthetic value behavioural trends because: (1) Cappadocia is one of the most popular destinations of the Japanese, South Korean and Chinese tourist (2) An increasing number of Far Eastern tourists have visited Turkey for their cultural vocational tour (3) The Far Eastern Market especially China is estimated to become one of the largest tourism markets in the World (4) The Far Eastern culture behaviour as a general rule chooses tour operators as their desired method of touring (5) Similarly, tour operators target them from a marketing strategy stand point because of the fact that they possess this form of touristic behaviour (6) The Far Eastern Geographical distance to Turkey dictates that tourists within these countries almost without exception use tour operators. According to Table 1 referred to above, the official tourist arrival numbers collated by the Cultural and Tourism Ministry Report were as follows: 203,592 Japanese, 159,084 South Korean and 114,582 Chinese tourists. Sekaran's Sampling Table specifies that after 100,000 tourists have been recorded, 384 samples must be completed. In this research 707 Japanese, South Korean and Chinese tourists came to Turkey using tour operators between February and April and 2013. That number is sufficient to enable the Sekarans' Sampling Tablet to be used. Convenience sampling, which is a non-probability sampling method was used. The study design included a qualitative methodology. Zhang's (2008) questions were adapted for use with tour operators and the questions were scrutinized and approved by 10 tour operator managers in Cappadocia. The questionnaire was translated into the Japanese, Chinese and Korean languages. A pilot test was employed on 150 Far East tourists who travelled using tour operators. Cronbach's Alpha assessment was found to be 0.865 within the main survey conducted using the 707 Far Eastern tourists. The research had 8 hypotheses which are set out below:

$\mathbf{H}_{1}$ : There is a meaningful difference between the tour operator selection criteria "Tour Operator's Product Design" and nationality.

$\mathbf{H}_{2:}$ There is a meaningful difference between the tour operator selection criteria "Sense of "Get Away"” and nationality.

$\mathbf{H}_{3}$ : There is a meaningful difference between the tour operator selection criteria "Opportunity to have fun" and nationality.

$\mathbf{H}_{4}$ : There is a meaningful difference between the tour operator selection criteria "Service Quality" and nationality.

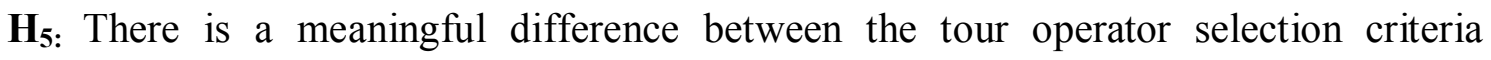

"Opportunity to interact with other people" and nationality.

$\mathbf{H}_{6:}$ There is a meaningful difference between the tour operator selection criteria "Prestige" and nationality. 


\section{A. Çelik 6/1 (2014) 32-41}

$\mathbf{H}_{7:}$ There is a meaningful difference between the tour operator selection criteria "Price" and nationality.

$\mathbf{H}_{8 \text { : }}$ There is a meaningful difference between the tour operator selection criteria "Loyalty Program" and nationality.

\section{Findings of the study}

It can be clearly seen from the results of table 2 that $48.4 \%$ (342) of the responses to the questionnaire were from males whereas $51.2 \%$ (362) of the responses were from females. The nationality data revealed that: $28.8 \%$ (204) were Japanese, $36.5 \%$ (258) were South Korean, $34.7 \%$ (245) were Chinese tourists. According to the income data the tourists who gave the highest response to the questionnaires (148) had an income of between $€ 60,000$ to $€ 79,999$. On the other hand the tourists who gave the least response (53) had an income of less than $€ 20,000$. Furthermore, the Age data revealed that: 31 $(4.3 \%)$ of the tourists responding to the questionnaire were younger than $21 ; 115$ $(16.3 \%)$ were between $21-30 ; 108(15.3 \%)$ were between $31-40 ; 134(19.0 \%)$ were between 41-50; 194 (27.4\%) were between 51-60 and 125 (17.7\%) were over 60 years of age. The Education part of Table 2 shows that 22 of the tourists responding to the questionnaire were educated to a standard lower than High School levels. However the highest response $204(28.9 \%)$ came from those tourists who were college graduates.

Table 2: Demographic Results of the Respondents ( $n=707)$

\begin{tabular}{|l|l|l|l|l|l|}
\hline & $\mathbf{f}$ & $\mathbf{\%}$ & & $\mathbf{f}$ & $\mathbf{\%}$ \\
\hline Gender & & & Age & & \\
Male & 342 & 48.4 & Less than 21 & 31 & 4.3 \\
Female & 362 & $\mathbf{5 1 . 2}$ & $21-30$ & 115 & 16.3 \\
Missing data & 3 & 0.4 & $31-40$ & 108 & 15.3 \\
Nationality & & & $41-50$ & 134 & 19.0 \\
Japan & 204 & 28.8 & $51-60$ & 194 & $\mathbf{2 7 . 4}$ \\
South Korea & 258 & $\mathbf{3 6 . 5}$ & Over 60 & 125 & 17.7 \\
Chinese & 245 & 34.7 & & & \\
\hline Income & & & Education & & \\
Less than $€ 20,000$ & 53 & 7.5 & Less than high school & 22 & 3.1 \\
$€ 20,000$ to $€ 39,999$ & 102 & 14.4 & High School & 130 & 18.4 \\
$€ 40,000$ to $€ 59,999$ & 136 & 19.2 & Some college-two years & 204 & 11.3 \\
$€ 60,000$ to $€ 79,999$ & 148 & $\mathbf{2 0 . 9}$ & College degree & 176 & 24.9 \\
$€ 80,000$ to $€ 99,999$ & 91 & 12.9 & Graduate degree & 88 & 12.4 \\
Over $€ 100,000$ & 130 & 18.4 & Postgraduate degree & & \\
Missing data & 47 & 6.6 & & \\
\hline
\end{tabular}

Table 3 shows the main attractions that motivated the Japanese, Chinese and South Korean tourists to come to Turkey for a vacation. The most important motivational purpose for the Japanese tourists was "visiting the underground city" $(21.73 \%)$ whereas "trekking" (1.53\%) attracted the least percentage. The most important motivational purpose for the Chinese tourist was "Leisure" (16.88\%) again contrary to this "trekking" $(1.86 \%)$ attracted the least percentage. For the South Korean tourists "Culture" was the top attraction $(21.10 \%)$ whereas "trekking " $(2.88 \%)$ was the most unpopular. Reviewing the result as a whole "visiting the underground city" attracted the most percentage points $(18,10 \%)$ but "trekking" was considered the least popular with a markedly small percentage $(2,10 \%)$. 
A. Çelik 6/1 (2014) 32-41

Table 3: Findings of travel characteristic to Cappadocia $(n=707)$

\begin{tabular}{|l|l|l|l|l|l|l|l|l|}
\hline \multirow{2}{*}{} & \multicolumn{7}{|c|}{ Nationality } & \multicolumn{2}{c|}{} \\
\cline { 2 - 9 } & \multicolumn{2}{|c|}{ Japan } & \multicolumn{2}{c|}{ China } & \multicolumn{2}{c|}{ South Korea } & \multicolumn{2}{c|}{ Total } \\
\cline { 2 - 9 } & $\mathrm{f}$ & $\%$ & $\mathrm{f}$ & $\%$ & $\mathrm{f}$ & $\%$ & $\mathrm{f}$ & $\%$ \\
\hline Visiting purpose & & & & & & & & \\
Underground City & 156 & 2.73 & 109 & 13.52 & 149 & 1953 & 414 & 18.10 \\
Open Air Museum & 126 & 17.55 & 88 & 1092 & 88 & 1153 & 302 & 13.21 \\
Religious & 30 & 4.18 & 29 & 3.60 & 68 & 8.91 & 127 & 5.55 \\
Trekking & 11 & 1.53 & 15 & 1.86 & 22 & 2.88 & 48 & 2.10 \\
Ballooning & 96 & 13.37 & 103 & 12.78 & 82 & 10.75 & 281 & 12.29 \\
Adventure & 24 & 3.34 & 38 & 4.71 & 21 & 2.75 & 83 & 3.63 \\
Pleasure & 51 & 7.10 & 98 & 12.16 & 24 & 3.15 & 173 & 7.56 \\
Culture & 92 & 12.81 & 119 & 14.76 & 161 & 21.10 & 372 & 16.27 \\
Leisure & 64 & 8.92 & 136 & 16.88 & 48 & 6.29 & 248 & 10.84 \\
Educational & 14 & 1.95 & 21 & 2.61 & 33 & 4.33 & 68 & 2.97 \\
Local Food\&Beverage & 54 & 7.52 & 50 & 6.20 & 67 & 8.78 & 171 & 7.48 \\
& & & & & & & & \\
\hline
\end{tabular}

As can be seen from table $45.25 \%$ of the Far Eastern tourists package holidays were booked in 5 stars hotels and only $0.7 \%$ in pensions. $13.5 \%$ were booked in boutique hotel showing a growing popularity for this type of hotel by the Far Eastern tourism market in Cappadocia. Also within the scope of our research it was found that a high proportion of Far Eastern tourists preferred to visit Cappadocia with their "family" $(45.8 \%)$ and there was a low preference level for "organized group travel" (11.7\%.)

Table 4: Findings of package tour components of Far Eastern Tourists $(n=707)$

\begin{tabular}{|l|l|l|l|l|l|}
\hline & $\mathbf{f}$ & $\mathbf{\%}$ & & $\mathbf{f}$ & $\mathbf{\%}$ \\
\hline Accommodation & & & Duration of Tour & & \\
5 Stars Hotel & 371 & 52.5 & Daily & 4 & 0.6 \\
4 Stars Hotel & 158 & 22.3 & 2 Days & 20 & 2.8 \\
3 Stars Hotel & 55 & 7.8 & 3 Days & 29 & 4.1 \\
Boutique Hotel & 94 & 13.3 & 4 Days & 19 & 2.7 \\
Cave Hotel & 17 & 2.4 & One week & 148 & 20.9 \\
Pension & 5 & 0.7 & More than 7 Days & 487 & 68.9 \\
Missing Value & 7 & 1 & & & \\
\hline Travel with & & & Hear about tour operator & & \\
Only myself & 30 & 4.2 & Past Experience & 217 & 30.7 \\
With family & 324 & 45.8 & Internet & 200 & 28.3 \\
With friends & 178 & 25.2 & Friends' recommendation & 101 & 14.3 \\
With colleagues & 88 & 12.4 & Corporate contact & 103 & 14.6 \\
Organized Group Travel & 83 & 11.7 & Visitor centre's brochures & 65 & 9.2 \\
Missing Value & 4 & 0.6 & & & \\
\hline
\end{tabular}

It can also be seen that a significantly high percentage of Far Eastern tourists visited Cappadocia for more than 7 days $(68.9 \%)$ and only a very small percentage did a day trip excursion $(0.6 \%)$. The last question concerning how the tourists came to "hear about the tour" (allowing for more than one answer) produced interesting percentage findings $30.7 \%$ said from past experience which was the most prominent selection by the Far Eastern tourists. Whereas the "Visitor Centre's Brochures" was found to be the least prominent selection. 
A. Çelik 6/1 (2014) 32-41

Table 5: Result of one-way ANOVA on mean difference of tour operator selection by the nationality $(n=707)$

\begin{tabular}{|c|c|c|c|c|c|}
\hline Items $^{\text {a }}$ & Group & $\mathbf{n}$ & $\bar{X} \mp S_{x}$ & $\mathbf{F}$ & $p$ \\
\hline \multirow[t]{3}{*}{ Tour Operator's Product Design } & Japanese & 203 & $4,38^{* *} \pm 0,05$ & \multirow[t]{3}{*}{11,267} & \multirow[t]{3}{*}{, 000} \\
\hline & South Korean & 258 & $\mathbf{4 , 0 0} \pm 0,06$ & & \\
\hline & Chinese & 245 & $4,17 \pm 0,04$ & & \\
\hline \multirow[t]{3}{*}{ Sense of "Get Away" } & Japanese & 200 & $\mathbf{3 , 2 0} * \pm 0,08$ & \multirow[t]{3}{*}{44,632} & \multirow[t]{3}{*}{,000 } \\
\hline & South Korean & 258 & $3,90 \pm 0,05$ & & \\
\hline & Chinese & 246 & $3,98 \pm 0,04$ & & \\
\hline \multirow[t]{3}{*}{ Opportunity to have fun } & Japanese & 197 & $\mathbf{3 , 5 3} \pm 0,08$ & \multirow[t]{3}{*}{37,624} & \multirow[t]{3}{*}{,000 } \\
\hline & South Korean & 258 & $4,02 \pm 0,05$ & & \\
\hline & Chinese & 246 & $4,28 \pm 0,04$ & & \\
\hline \multirow{3}{*}{ Service Quality } & Japanese & 201 & $4,26 \pm 0,05$ & \multirow[t]{3}{*}{1,443} & \multirow[t]{3}{*}{,237 } \\
\hline & South Korean & 256 & $\mathbf{4 , 2 0} \pm 0,05$ & & \\
\hline & Chinese & 246 & $4,33 \pm 0,04$ & & \\
\hline \multirow{3}{*}{$\begin{array}{l}\text { Opportunity to interact with } \\
\text { other people }\end{array}$} & Japanese & 200 & $\mathbf{3 , 5 5} \pm 0,06$ & \multirow[t]{3}{*}{3,654} & \multirow[t]{3}{*}{0,26} \\
\hline & South Korean & 256 & $3,59 \pm 0,06$ & & \\
\hline & Chinese & 246 & $3,77 \pm 0,05$ & & \\
\hline \multirow[t]{3}{*}{ Prestige } & Japanese & 198 & $3,63 \pm 0,08$ & \multirow[t]{3}{*}{6,811} & \multirow[t]{3}{*}{,001 } \\
\hline & South Korean & 254 & $\mathbf{3 , 5 2} \pm 0,06$ & & \\
\hline & Chinese & 246 & $3,85 \pm 0,05$ & & \\
\hline \multirow[t]{3}{*}{ Price } & Japanese & 203 & $4,18 \pm 0,05$ & \multirow[t]{3}{*}{3,270} & \multirow[t]{3}{*}{,039 } \\
\hline & South Korean & 254 & $\mathbf{3 , 9 8} \pm 0,05$ & & \\
\hline & Chinese & 246 & $4,08 \pm 0,05$ & & \\
\hline \multirow[t]{3}{*}{ Loyalty Program } & Japanese & 203 & $4,24 \pm 0,05$ & \multirow[t]{3}{*}{11,601} & \multirow[t]{3}{*}{,000 } \\
\hline & South Korean & 250 & $4,30 \pm 0,05$ & & \\
\hline & Chinese & 246 & $\mathbf{3 , 9 5} \pm 0,05$ & & \\
\hline \multicolumn{6}{|c|}{$\begin{array}{l}\text { ** } 0.005 \text { significance level } \\
{ }^{a} \text { Remark: Five-point Likert scale was used for rating the importance of each criteria, ranging from } 1 \text { (very } \\
\text { unimportant) to } 5 \text { (very important) } \\
* \text { The lowest mean among criteria. }\end{array}$} \\
\hline
\end{tabular}

One way ANOVA analysis was used to accurately assess the differentiation of the tour operator selection criteria by nationality. The results of the one way ANOVA analysis for 6 of the selection criteria showed some differential between nationalities and the other 2 selection criteria showed only minimal differentiation. Among the tour operator selection criteria by nationality there was no significant difference with "Service Quality" and "Opportunity to interact with other people". However "Tour Operator's Product Design", "Sense of "Get Away", "Opportunity to have fun", "Prestige", "Price" and "Loyalty Program" items showed some meaningful differential between nationalities. For example: $\mathbf{H}_{1}$, “Tour Operator's Product Design" (Japanese: 4.38 , South Korean: 4.00 and Chinese: 4.17) $\mathbf{H}_{2}$ "Sense of "Get Away" (Japanese: 3.20, South Korean:3.90 and Chinese:3.98) , $\mathbf{H}_{\mathbf{3}}$ "Opportunity to have fun" (Japanese:3.53, South Korean;4.02 and Chinese;4.28), $\mathbf{H}_{\mathbf{6}}$ "Prestige" (Japanese;3.63, South Korean;3.52 and Chinese:3.85), $\mathbf{H}_{7}$ "Price" (Japanese:4.18, South Korean:3.98 and Chinese:4.08), $\mathbf{H}_{\mathbf{8}}$ "Loyalty Program" (Japanese;4.24, South Korean; 430 and Chinese;3,95) are accepted; $\mathbf{H}_{4}$ "Service Quality" (Japanese 4.26: South Korean: 4.20 and Chinese: 4.33), $\mathbf{H}_{5}$ "Opportunity to interact with other people" (Japanese 3.55: South Korean 3.59: Chinese 3.77) hypothesises were rejected under nationality $(\mathrm{p}<0.005)$. 


\section{A. Çelik 6/1 (2014) 32-41}

\section{Research Limitations}

Research was conducted with only a limited part of the Far Eastern tourism market i.e. Japan, South Korea and China. Further useful research could be conducted utilising the rest of the Far Eastern market for example Indonesia, India, Singapore, Malaysia, Thailand, Bangladesh, and Pakistan. Different market segments within Europe and America could also add to important statistical data and useful findings for the tourism industry. Furthermore only six tour operator selection criteria were used to determine the results and the design and number of the criteria could usefully be increased.

\section{Conclusion}

Looking at the results generally it can be said that the Japanese are more product design orientated than Chinese and South Korean tourists. Also The Chinese have a greater "sense of get away" orientation than the South Korean and Japanese. The Chinese show a greater need for "Opportunity to have fun" orientation than the South Korean and Japanese. Similarly, the Chinese are more "Prestige" orientated than the Japanese and South Korean. Interestingly, the Japanese are more "price" orientated than the Chinese and South Korean tourists. As a separate finding, The South Korean are more "Loyalty Program" orientated than the Japanese and South Korean.

We can also conclude from this study that "Service quality" is the most important criteria for all three nationalities. As a result of this tour operators should give more importance to tour service quality. It would also be advisable for package tours to provide more quality transportation services, quality hotel services and quality food and beverage services.

By way of contrast, the "Opportunity to interact with other people" criteria had the least dominance amongst the three nationalities. Far Eastern tourists don't, as a rule, need to socialize to any great degree on a tour it is for this reason that they generally choose cultural tours. Also they prefer to participate more on package tours with their family. So tour operators give less importance to the promotion of socialising in brochures and promotional videos for Far Eastern tourists.

Tour operators product design is given high importance by the Japanese but low importance by Koreans; Sense of "Get Away" is given high importance by Chinese but low importance by Japanese; Opportunity to have fun" is given high importance by Chinese but low importance by Japanese. However all respondents gave high importance to service quality but moderate importance to Opportunity to interact with other people. All the nationalities gave moderate importance to Prestige but high importance to price; Korean and Japanese tourists gave high importance to loyalty programs.

The resulting data revealed that the Far Eastern tourist market shows similarities in tour operator selection criteria they commonly give importance to service quality and price. They also give importance to loyalty programs and tour operator product design.

Thus we can advise tour operator managers, with some certainty, that need to focus on: product design, service quality, price and loyalty programs. On the other hand, from the results of this study, it would appear that it would be prudent for them to give less importance commercially to prestige and group interaction. 


\section{A. Çelik 6/1 (2014) 32-41}

In conclusion, from the mean scores taken from the Japanese, Chinese and South Korean tourists' tour operator selection criteria, we are able to say with some confidence that the Far Eastern market has similar behavioural results to the current literature (Woodside \& Lawrence, 1985; Sheldon \& Fox, 1998; Pizam \& Sussman, 1995; Pizam \& Jeong, 1996) leading on from this we can also say that the Korean tourist has very few different behavioural patterns from the Japanese and Chinese. Oral \& Çelik (2013) found meaningful correlation between Far Eastern tourists' aesthetic value experiences of tourism product and customer satisfaction. Çelik (2013) found meaningful correlation between Far Eastern tourists' experiential value experiences of tour operator with customer satisfaction and customer loyalty. Turkey is a heritage destination therefore the Turkish tourism market of the future should essentially be focusing commercially on the Far Eastern market because the attractions within Turkey are deeply seated in history and culture which are at one with the main needs and interests of the Far Eastern tourist. This study will therefore assist Far Eastern focused tour operators to shape their strategic marketing management.

\section{References}

Ahmed, Z. \& Krohn, F. (1992). Understanding the Unique Consumer Behavior of Japanese Tourists. Journal of Travel and Tourism Marketing. 1(3), 73-86.

Business Korea 'The way of Korean travelling, Koreans are strange?" Business Korea, 9 (2) 29 .

Cavlek, N. (2002). Tour operators and destination safety. Annals of Tourism Research, $29(2), 478-496$.

Çelik A. (2013). Turizmde Deneyimsel Pazarlama: Tur Operatörlerine Yönelik Bir Uygulama, Basılmamış Doktora Tezi, Dokuz Eylül Üniversitesi, Sosyal Bilimler Enstitüsü, İzmir

Gartner W. C. \& Bachri T. (1994). Tour Operators' Role in the Tourism Distribution System: An Indonesian Case Study. Journal of International Consumer Marketing. Vol.6, Issue 3-4.161-179.

Hall, E. T. (1969). The silent language. Greenwich, CT: Fawcett.

Hofstede, G. (1991). Organization and cultures: Software of the mind. New York: McGraw-Hill.

Horner, P. (1996). Travel Agency Practice.Longman:England..

Kotler, P., Bowen, J. \& Makens, J. (1996) Marketing and Hospitality for Tourism (Upper Saddle River:Prentice Hall).

Ministry of Culture and Tourism -Kültür ve Turizm Bakanlığı. (2013). Sınır Giriş Çıkış İstatistikleri. http:/www.ktbyatirimisletmeler.gov.tr/TR,9854/sinir-giris-cikisistatistikleri.html. (12.01.2013).

Luk, M. (1993). Hong Kong holidaymakers taken for a ride. Window, 2(19), 12-13

Mak. J. (2004). Tourism and the Economy Understanding the Economics of Tourism. Hawai Press. 


\section{A. Çelik 6/1 (2014) 32-41}

Mok, C., \& Armstrong, R. W. (1995). Leisure travel destination choice criteria of Hong Kong residents. Journal of Travel \& Tourism Marketing, 4(1), 99-104.

Mok, C., \& DeFranco, A. L. (1999). Chinese Cultural Values: Their Implications for Travel and Tourism Marketing. Journal of Travel \& Tourism Marketing. 8(2), 99114.

Oral, S. \& Çelik, A. (2013). Türkiye'yi Ziyaret Eden Turistlerin Estetik Deneyimleri Üzerine Bir Araştırma. İşletme Araştırmaları Dergisi, 5(4), 170-190.

Pizam, A., \& Sussman, S. (1995). Does nationality affect tourist behavior? Annals of Tourism Research, 22(4), 901-917.

Pizam, A. \& Jeong, G. H. (1996). Cross-cultural Tourist Behaviour Perception of Korean Tour-Guides. Tourism Management. 17(4): 277-286.

Reilly, R.T. (1982). Handbook of Professional Tour Management. Delmar Publishers Inc.: New York.

Sekaran, U. (2000). Research Methods for Business: A Skill-Building Approach. UK: Wiley\&Sons.

Sheldon, P., \& Fox, M. (1988). The role of foodservice in vacation choice and experience: A cross-cultural analysis. Journal of Travel Research, 27(3), 9-15.

Surman, B. (2009). The Search for the Real Thin Japanese Tourism in Britain. Editor Sylvie Guichard \& Okpyo Moon. Japanese Tourism and Travel Culture. New York: Routledge.

Trompenaars, A. (1994). Riding the waves of culture: Understanding diversity in global business. Burr Ridge, IL: Irwin.

Wong, S. C. and Kwong Y. W. (2004). Outbound Tourists' Selection Criteria for Choosing All-Inclusive Package Tours. Tourism Management. 25, 581-592.

Woodside, A. G., \& Lawrence, J. (1985). Step two in benefit segmentation: Learning the benefits realized by major travel markets. Journal of Travel Research, 24(1), $7-13$.

Varley, P. (2000) Japanese Culture, 4th edn, updated and expanded. Honolulu: University of Hawai Press

Yale, P. (1995). The Business of Tour Operations. Longman: England..

Zhang, J. (2008). Brand Experiential Value Scales For Limited-Service Hotels. Unpublished Doctoral Dissertation. Indiana: Purdue University. 